\title{
Clinical and epidemiological aspects of prematurity in a Normal Delivery Center, São Paulo, Brazil
}

\author{
Aspectos clínicos e epidemiológicos da prematuridade em um Centro de Parto Normal, \\ São Paulo, Brasil
}

\author{
Miriam Siqueira do Carmo Rabello ${ }^{1}$, Sonia Maria Oliveira de Barros ${ }^{2}$
}

\begin{abstract}
Objective: To present clinical and epidemiological aspects of prematurity in a Normal Delivery Center, and to describe outcomes. Methods: A cross-sectional retrospective study, with 189 medical records of premature, single, and living fetuses, with gestational ages between 25 and 36.6 weeks. Results: The prevalence of preterm births was $7.8 \%$, and $23.2 \%$ in adolescent mothers. The most frequent obstetric complication was premature rupture of ovular membranes $(35.4 \%)$, followed by hypertensive syndrome (18.5\%). Cesarean section was performed in $33 \%$ of cases. The Apgar score in the 1st minute was $<7$ in $36.0 \%$ of cases, and in the 5 th minute of life, in $9.5 \%$ of cases. Conclusion: Among the aspects studied, results showed that the prevalence of preterm births was higher than expected for the adolescent mothers, however, with a satisfactory perinatal outcome.
\end{abstract}

Keywords: Obstetrical nursing; Parturition; Natural childbirth; Obstetric labor, premature

\section{RESUMO}

Objetivo: Apresentar aspectos clínicos e epidemiológicos da prematuridade em um Centro de Parto Normal e descrever resultados perinatais. Métodos: Trata-se de um estudo transversal, retrospectivo, com 189 prontuários clínicos de partos prematuros com fetos únicos, vivos, com idade gestacional entre 25 e 36,6 semanas. Resultados: A prevalência de prematuridade foi de $7,8 \%$, sendo $23,2 \%$ em mães adolescentes. A intercorrência obstétrica mais frequente foi a rotura prematura das membranas ovulares $(35,4 \%)$, seguida da síndrome hipertensiva (18,5\%). 0 parto cesáreo foi realizado em $33 \%$ dos casos. 0 índice de Apgar, no 10. minuto, foi $<7$ em $36,0 \%$ dos casos e, no 5o. minuto de vida em 9,5\% dos casos. Conclusão: Entre os aspectos estudados, os resultados mostraram que a prevalência de prematuridade foi maior do que 0 esperado para as mães adolescentes, mas com resultados perinatais satisfatórios.

Descritores: Enfermagem obstétrica; Parto; Parto normal; Trabalho de parto prematuro

\section{INTRODUCTION}

Premature delivery is an important obstetric problem, since it is responsible for more than $75 \%$ of mortality and morbidity among newborns ${ }^{(1,2)}$. It is defined as a delivery that occurs between 22 nd and 36th weeks and 6 days of gestation ${ }^{(1)}$.

In Brazil, the rate of prematurity varied between 5 and $15 \%{ }^{(3,4)}$. In hospitals that treat high-risk pregnancies, such as the Obstetric Department of the Universidade Federal de São Paulo (UNIFESP), premature deliveries occur in about $20 \%$ of cases $^{(5)}$.

Normal Delivery Center (CPN, acronym in Portuguese) is defined as an intrahospital unit outside of the operating room, destined to perform vaginal deliveries, with a physical structure designed to receive the woman about to give birth and her companion. Since labor and delivery of many high-risk pregnant women follows a normal course, assistance in the CPN is also applied to these women ${ }^{(6)}$.

In studies about premature deliveries ${ }^{(7)}$, it was been observed that the quality of assistance given during the period that antecedes the delivery may bring benefits or harm to the premature newborn, evidencing the

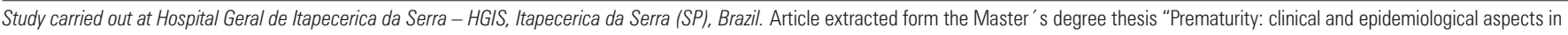
a Normal Delivery Center", submitted to the Universidade Federal de São Paulo - UNIFESP, São Paulo (SP), Brazil.

${ }^{1}$ Graduate Program (Master's degree), Escola Paulista de Enfermagem, Universidade Federal de São Paulo - UNIFESP, São Paulo (SP), Brazil.

${ }^{2}$ Escola Paulista de Enfermagem, Universidade Federal de São Paulo - UNIFESP, São Paulo (SP), Brazil.

Corresponding author: Sonia Maria Oliveira de Barros - Departamento de Enfermagem da Universidade Federal de São Paulo - Rua Napoleão de Barros, 754 - Vila Clementino - CEP 04024002 - São Paulo (SP), Brazil - Tel.: 11 5573-3371 -E-mail: sbarros@unifesp.br

Received on: Sept 8, 2010 - Accepted on: Oct 28, 2011

Conflicts of interest: none
} 
particular importance of monitoring fetal heartbeats during labor and premature deliveries, preventing acidosis and intraventricular hemorrhage, thus reducing neonatal morbidity.

Prevention of the premature delivery has been studied for a long time, and the various associated risk factors that can indicate which pregnant women have a greater probability of developing premature deliveries are known.

\section{OBJECTIVES}

The objective of this research was to present the behavior of some clinical and epidemiological variables related to prematurity; to describe the practice of selective episiotomy in premature births; and to describe the perinatal results in assistance to premature deliveries.

\section{METHODS}

\section{Type of study and location}

A descriptive and retrospective study was carried out in which the clinical files were researched of women who had given birth at the Hospital Geral de Itapecerica da Serra (HGIS) during a one-year period, and who satisfied the inclusion criteria, i.e., any type of delivery that occurred during the period selected for the study; gestational age at the time of birth between 22 and 36 weeks and 6 days, assessed by the Capurro ${ }^{(8)}$ or New Ballard ${ }^{(9)}$ Method.

During the year 2002, a total of 4048 deliveries were performed at the HGIS, 315 of which had gestational ages under 36 weeks and 6 days. Of these, 189 clinical files were analyzed, which made up the study population, representing $60 \%$ of the total number of premature deliveries during the period.

Excluded were files with twin births, newborns with congenital malformations, stillbirths, and incomplete clinical files, totaling 126 cases.

The following obstetric variables were analyzed: maternal age, parity, prior history of prematurity, number of prenatal clinical visits, records of clinical and obstetric complications during the present gestation, cervical dilation at the time of hospital admission, condition of the amniotic membranes at admission, type of delivery, and perineal results after a vaginal delivery.

The perinatal variables studied were weight at birth, Apgar assessment values, hospitalization unit of the newborn after birth, and neonatal mortality.

Data collection was initiated after the approval by the Research Ethics Committees of the Universidade Federal de São Paulo (UNIFESP) and of HGIS. All the requirements of CNS Resolution 196 were met in the conduction of this study.

\section{RESULTS}

The prevalence of prematurity at the site of the study was $7.8 \%$ of all deliveries during the study period.

Mothers aged under 17 years corresponded to $9.5 \%$ of the sample analyzed. Also considering mothers with ages between 18 and 19 years (13.7\%), the population of adolescents assisted was $23.2 \%$. The results showed that $39 \%$ of the population studied was of primiparous and $5.8 \%$ was of multiparous women; the prior history of prematurity was positive in $11.1 \%$ of cases. The number of prenatal visits varied from more than six $(24.3 \%)$ to none $(15.9 \%)$ data presented on table 1 .

Table 1. Distribution of the population studied according to selected obstetric variables

\begin{tabular}{lccc}
\hline Obstetric variables & $\mathbf{n}=\mathbf{1 8 9}$ & $\%$ & Mean $\mathbf{\text { SD }}(\%)$ \\
\hline Maternal age & & & \\
$\leq 17$ & 18 & 9.5 & \\
$18 \mid-20$ & 26 & 13.7 & \\
$20 \mid-35$ & 121 & 64.0 & \\
$\geq 35$ & 24 & 12.8 & \\
Total & 189 & 100.0 & $25.5 \pm 7.3$ \\
Parity & & & \\
0 & 74 & 39.2 & \\
$1 \mid-3$ & 70 & 37.0 & \\
$3 \mid-5$ & 34 & 18.0 & \\
$\geq 5$ & 11 & 5.8 & \\
Total & 189 & 100.0 & $2.5 \pm 1.8$ \\
Prior history of prematurity & & & \\
Yes & 21 & 11.1 & \\
No & 168 & 88.9 & \\
Number of prenatal visits & & & \\
0 & 30 & 15.9 & \\
$1 \mid-6$ & 113 & 59.8 & \\
$\geq 6$ & 46 & 24.3 & \\
\hline Total & 189 & 100.0 & \\
& & & \\
& & &
\end{tabular}

Of the obstetric complications, premature rupture of the membranes occurred in $35.4 \%$ of the cases, pregnancyinduced hypertensive syndrome was found in $18.5 \%$ of the sample; oligoamnios, in $10.6 \%$; and gestational diabetes was identified in $2.6 \%$ of the cases (Table 2).

Table 2. Clinical and obstetric complications during the current gestation, observed at admission of the pregnant woman/woman in labor

\begin{tabular}{lcc}
\hline Complications & $\mathbf{n}^{*}$ & $\%$ \\
\hline PROM & 67 & 35.4 \\
Hypertensive syndrome & 35 & 18.5 \\
Oligoamnios & 20 & 10.6 \\
PMD & 11 & 5.8 \\
UTI & 10 & 5.3 \\
Diabetes & 5 & 2.6 \\
\hline
\end{tabular}

${ }^{*} \mathrm{n}=189$

A woman in labor may present with one or more associated complications.

PROM: premature rupture of the ovular membranes; PMD: premature membrane detachment; UTI: urinary tract infection. 
Of the variables found at the time of delivery, the selectively performed episiotomy was done in $45.6 \%$ of cases, and vaginal deliveries were assisted by obstetric nurses who, when necessary, requested medical evaluation. The rate of caesarean sections was $33.9 \%$ of cases (Table 3). Data on cervical dilation, amniotic membranes at birth, and perineal condition are also displayed on table 3 .

Table 3. Distribution of the population studied according to obstetric variables at the time of admission, and obstetric care given during the perinatal period

\begin{tabular}{lccc}
\hline Variable & N & $\%$ & Mean $\pm \mathbf{S D}(\%)$ \\
\hline Cervical dilation (cm) & & & $3.7 \pm 3.4$ \\
$\leq 2$ & 52 & 27.0 & \\
3 I-I 5 & 26 & 13.7 & \\
6 I-I 8 & 26 & 13.7 & \\
9 I-I 10 & & & \\
Amniotic membranes & 94 & 50.3 & \\
Intact & 92 & 49.2 & \\
Ruptured & 3 & 1.6 & \\
No record & & & \\
Type of delivery & 64 & 33.9 \\
C-Section & 125 & 66.1 \\
Vaginal & 189 & 100 \\
Total & & \\
Perineal conditions & 44 & 35.2 \\
Intact & 24 & 19.2 \\
1 $^{\text {st }}$ degree laceration & 0 & 0 \\
$2^{\text {nd }}$ degree laceration & 57 & 45.6 \\
Episiotomy & 125 & 100 \\
\hline Total & &
\end{tabular}

As to the perinatal results found, we noted a greater incidence of births between the $34^{\text {th }}$ and the $36^{\text {th }}$ weeks of gestation, as these represented $69.3 \%$ of the total population. The highest frequency was of children with low weight at birth, with weights between 2000 and $2499 \mathrm{~g}(39.2 \%)$ of the population studied. The Apgar score for the newborns studied was $>7$ in $90.5 \%$ of cases (Table 4).

As to the destination of the newborns after delivery, results showed that $45.5 \%$ were sent to accommodations rooming in with their mothers, and $54.5 \%$ were sent to the Neonatal Intensive Care Unit (NICU) (Table 5).

Among the neonatal deaths that occurred during the period of this study, three occurred with gestational ages between 25 and 27 weeks of gestation, characterizing extreme prematurity and mortality. The causes of newborn mortality are shown on Table 6.
Table 4. Distribution of the population studied according to perinatal variables

\begin{tabular}{|c|c|c|}
\hline Variable & $\mathbf{n}=189$ & $\%$ \\
\hline \multicolumn{3}{|l|}{ Gestational age (weeks) } \\
\hline $25 \mid-28$ & 3 & 1.6 \\
\hline $28 \mid-31$ & 10 & 5.3 \\
\hline $31 \mid-34$ & 45 & 23.8 \\
\hline $34 \mid-36$ & 131 & 69.3 \\
\hline \multicolumn{3}{|l|}{ Weight at birth (g) } \\
\hline$>1000$ & 4 & 2.1 \\
\hline $1000 \mid-1500$ & 24 & 12.2 \\
\hline $1500 \mid-2000$ & 35 & 18.5 \\
\hline $2000 \mid-2500$ & 82 & 39.2 \\
\hline$\geq 2500$ & 54 & 28.0 \\
\hline \multicolumn{3}{|l|}{$1^{\text {st }}$ minute Apgar } \\
\hline$\leq 7(1$ a 7$)$ & 68 & 36.0 \\
\hline$>7$ (8 a 10) & 121 & 64.0 \\
\hline \multicolumn{3}{|l|}{$5^{\text {th }}$ minute Apgar } \\
\hline$\leq 7(1$ a 7$)$ & 18 & 9.5 \\
\hline$>7(8$ a 10) & 171 & 90.5 \\
\hline \multicolumn{3}{|c|}{ Final destination of the NB } \\
\hline Hospital discharge & 182 & 96.3 \\
\hline Death & 7 & 3.7 \\
\hline Total & 189 & 100.0 \\
\hline
\end{tabular}

Table 5. Immediate destination of the newborn

\begin{tabular}{lcc}
\hline Destination & $\mathbf{n}$ & $\mathbf{R F} \%$ \\
\hline Rooming in with mother & 86 & 45.5 \\
NICU & 103 & 54.5 \\
\hline Total & 189 & 100.00 \\
\hline
\end{tabular}

NICU: Neonatal Intensive Care Unit; RF: Relative Frequency

Table 6. Cause of neonatal deaths studied

\begin{tabular}{|c|c|c|}
\hline $\begin{array}{l}\text { Weight at } \\
\text { birth }(g)\end{array}$ & $\begin{array}{l}\text { Gestational } \\
\text { age (weeks) }\end{array}$ & Causes of deaths \\
\hline 710 & 25 & Neonatal sepsis \\
\hline 850 & 26 & $\begin{array}{l}\text { Respiratory insufficiency, hyaline membrane } \\
\text { pulmonary disease, pneumothorax on the right, } \\
\text { and extreme prematurity }\end{array}$ \\
\hline 1140 & 29 & $\begin{array}{l}\text { Late sepsis, necrotizing enterocolitis, and } \\
\text { clotting disorder }\end{array}$ \\
\hline 1700 & 31 & $\begin{array}{l}\text { Prematurity, neonatal anoxia, early } \\
\text { cardiorespiratory insufficiency }\end{array}$ \\
\hline 1460 & 34 & $\begin{array}{l}\text { Septic shock, late neonatal sepsis, } \\
\text { bronchopneumonia, prematurity, and hyaline } \\
\text { membrane pulmonary disease }\end{array}$ \\
\hline 2230 & 34 & Bilateral pneumothorax \\
\hline 2635 & 35 & $\begin{array}{l}\text { Severe pulmonary hypertension, early sepsis, } \\
\text { moderate perinatal anoxia }\end{array}$ \\
\hline
\end{tabular}

\section{DISCUSSION}

Today prematurity is considered one of the primary causes of perinatal morbidity and mortality, and it is responsible for severe immediate damage to newborns and for late sequelae. The incidence of premature births is variable, since its etiology is based on social, biological, ethnic, and behavioral factors, among others ${ }^{(1,2)}$. 
According to the Ministry of Health of Brazil (4), in 1996, the rate of prematurity recorded was 5.5 and $5.8 \%$ in Brazil and in the state of Sao Paulo, respectively. Ten years later, in 2005, the rate was 5.8\% in Brazil and 7.5\% in São Paulo state, respectively. In this way, the rate of prematurity at the HGIS was similar to the state's rate of prematurity.

Also according to the Ministry of Health ${ }^{(10)}$, in São Paulo, during the year 2002, the adolescent population was responsible for $18.4 \%$ of the deliveries. This population is inserted in the high-risk pregnancy group, both from the psychosocial and the biological point of view ${ }^{(11)}$.

In the population studied, adolescents represented practically one fourth of the sample, evidencing a potential of very high-risk pregnant individuals. Nevertheless, it is worth pointing out that the highest numbers found refer to pregnant women between 18 and 19 years of age, considered obstetrically equivalent to adult pregnant women in terms of risks ${ }^{(11)}$.

Nulliparous or multiparous women are considered a risk factor for premature birth when there is a history of more than five prior deliveries ${ }^{(12)}$. Literature also suggests that the prior history of premature birth is also a risk factor for its occurrence ${ }^{(5,13,14)}$. In the present study, the greater number of cases was seen in nulliparous women, which favored the occurrence of prematurity, and on the other hand, in those who were multiparous, the number that reported a prior history of prematurity corroborates data in literature ${ }^{(12)}$.

Adequate prenatal assistance is an isolated factor of greater interference for a decrease in premature births. Precociousness at the first prenatal visit is significantly associated with the number of full-term gestations and with the weight at birth ${ }^{(15)}$. Despite the availability of governmental programs of prenatal care, a large proportion of the population in this study had no prenatal visit, which would mean greater risks for premature birth.

Various obstetric complications also contribute towards the occurrence of a premature birth, including premature rupture of the ovular membranes ${ }^{(16,17)}$, which occurs in pregnant women not in labor and with more than 20 weeks gestation. The mean incidence is $10 \%$ of the total number of births in western populations ${ }^{(17)}$. The rate found in this study, although a lot higher than what was cited, was similar to that referred by other authors, considering that it represents a majority of nulliparous women with gestational ages greater than 34 weeks $^{(18)}$. The perinatal result was affected more by prematurity than by premature membrane rupture ${ }^{(19)}$.

Pregnancy-induced hypertension is also a disorder that favors premature birth ${ }^{(20,21)}$. The frequency found in this study population was high, a finding that might be related, especially, to the absence of prenatal care in a large number of expectant mothers.
Oligoamnios affects about 3 to 5\% of gestations during the third trimester, and is rare during the second trimester, although it is related to premature births ${ }^{(22)}$. The population in this study had a higher frequency than what had been referred, which contributed to the occurrence of premature deliveries.

Elective prematurity represents 20 to $30 \%$ of premature deliveries. In high-risk obstetric services, such as the Obstetrics Clinic of the Hospital das Clínicas da Faculdade de Medicina da Universidade de São Paulo, practically $50 \%$ of the premature births result from maternal and/or fetal complications, with medical indications for interruption of the gestation ${ }^{(23)}$ by means of a caesarean section. In Brazil, the Ministry of Health ${ }^{(4)}$ is aware of the high rate of C-sections, which has stayed high for many years. In 2005, the Brazilian rate was $43.3 \%$, and in the State of Sao Paulo, approximately $50 \%$. In the present study, the rate of $\mathrm{C}$-sections proved lower than these data. In a systematic review of the Cochrane Library it was concluded that there was no evidence to support the practice of elective caesarean sections in premature deliveries, since it did not decrease the risk of neonatal death and could increase the risk of maternal morbidity ${ }^{(24)}$. In a study on elective prematurity ${ }^{(2)}$, a $94.4 \%$ rate of C-sections was identified. Other studies on prematurity or diseases during gestation that result in prematurity report that the high rates of C-sections $(51.2 \%, 52.5 \%$, and $56 \%)$ are justified by the high-risk population ${ }^{(18,25)}$. In the present study, the rate of cesarean sections was shown to be well below these values.

Vaginal premature delivery should occur in the least traumatic waypossible, considering the fragility of the fetus $^{(5)}$. The episiotomy was introduced as routine in these deliveries, although in the absence of consistent scientific indications of its efficacy ${ }^{(5)}$, with the intention of preventing cerebral hemorrhages and reducing perinatal asphyxia. Nevertheless, as per a systematic review, there are no data that support the assertion that the liberal use of episiotomy minimizes fetal head trauma ${ }^{(25,26)}$. At the Normal Delivery Center [CPN] of HGIS, selective episiotomy is recommended, and normal deliveries are assisted by obstetric nurses who, if necessary, request medical evaluation.

The gestational age of the expectant mothers who gave birth at the same hospital where the births of this population happened, was also similar to that reported in other studies referring to prematurity ${ }^{(27)}$.

Although the score given by the Apgar index for preterm newborns has restrictions, in the population studied, it was similar to that reported in other Brazilian studies on prematurity ${ }^{(28)}$.

As to the destination of the newborns, data show that even though they are premature, most of this 
group of newborns was discharged from the hospital approximately 48 hours after birth.

There are various causes of newborn death, however, low birth weight, that is, weight under $2,500 \mathrm{~g}$, is responsible for about 40 to $70 \%$ of neonatal deaths ${ }^{(29)}$. In the present study, neonatal mortality was high. Nonetheless, the lack of prenatal care in a large number of patients, the number of newborns with very low weights, and the very number of patients in the small sample analyzed, may explain this result. On the other hand, one must consider that, possibly, high-risk pregnancies under 32 weeks of gestational age should be assisted in a tertiary hospital, with pertinent material and human resources. The causes of neonatal mortality reflect this situation. Therefore, the preventable causes could be avoided by adequate prenatal care.

This study had limitations. It is a diagnosis of a situation with a relatively small number of cases. However, the findings reflect the conditions of care of a CPN in a general hospital in which some data reflect good results, due to measures that can be adopted by other institutions with similar structures.

On the other hand, despite the many strategies used over the years for prevention or treatment of premature deliveries, they have not been effective. Until new strategies are found, efforts are concentrated on the prevention of neonatal complications, using corticoids to accelerate fetal pulmonary maturity, antibiotics to prevent certain maternal, fetal and/or neonatal infections, and careful management for a nontraumatic delivery. Multi-professional assistance, with active participation of the obstetrics nurse, upholds quality obstetric care, enabling the use of the technology necessary for each case, and thus promoting satisfactory care for the expectant mother and her child.

\section{CONCLUSION}

Although various factors were identified which predispose to premature deliveries, the $7.8 \%$ incidence of prematurity was similar to that of the State of Sao Paulo.

Assistance for premature deliveries at the CPN of the HGIS proved adequate in relation to the rate of $\mathrm{C}$-sections, which was below the Brazilian average, and the non-performance of routine episiotomies.

Care of the newborn in the delivery room proved adequate. Neonatal mortality occurred primarily due to low-weight newborns.

\section{ACKNOWLEDGMENTS}

This project was subsidized by the National Council of Scientific and Technological Development (CNPq), Process No. 302556/2005-2.

\section{REFERENCES}

1. FEBRASGO. Manual de orientação e assistência pré-natal. Rio de Janeiro:Revinter; 2000.

2. Perroni AG, Bittar RE, Fonseca ESB, Messina MD, Marra KC, Zugaib M. Prematuridade eletiva: aspectos obstétricos e perinatais. Rev Bras Ginecol Obstet.1999;10(2):67-71.

3. Barros AJ, Santos IS, Victora CG, Victora CG, Albernaz EP, Domingues MR, et al. Coorte de nascimentos de Pelotas, 2004: Metodologia e descrição. Rev Saúde Pública. 2006;40(3):4002-13.

4. Brasil. Ministério da Saúde. Cadernos de informações de Saúde pública Região Sudeste [Internet]. [citado 2007 Set 19]. Disponível em: http://www.tabnet. datasus.gov.br-

5. Camano L, Souza E, Sass N, Mattar R. Obstetrícia - Guias de medicina ambulatorial e hospitalar UNIFESP - Escola Paulista de Medicina. Barueri: Manole. 2003.il.171-8.

6. Basile ALO, Pinheiro MSB, Miyashita NT. Centro de Parto Normal IntraHospitalar. São Caetano do Sul, SP: Yendis Editora; 2007.

7. Bottoms S. Delivery of the premature infant. Clin Obstet Gynecol.1995;38 (4):780-9.

8. Capurro H, Konichezky S, Fonseca D, Caldeyro-Barcia R. A simplified method for diagnosis of gestational age in the newborn infant. J Pediatr. 1978; 93(1):120-2.

9. Ballard JL, Khoury JC, Wedig K, Wang L, Eilers-Walsman BL, Lipp R. New Ballard include extremely premature infants. J Pediatr.1991;119(3):417-23.

10. Brasil. Ministério da Saúde. Vigilância em saúde: dados e indicadores selecionados. Secretaria de vigilância em saúde. Departamento de Análise de Situação em Saúde. Brasília, DF: Ministério da Saúde, 2003-ano 2, N2, Jan/ dez 2004.

11. Kumar A, Singh T, Basu S, Pandey S, Bhargava V. Outcome of teenage pregnancy. Indian J Pediatr. 2007;74(10):927-31.

12. World Health Organization (WHO). Integrated management of pregnancy and childbirth - Pregnancy, childbirth, postpartum and newborncare: A guide for essential practice. Geneva: World Health Organization; 2003.

13. Gama SG, Szwarcwald CL, Leal MC. Experiência de gravidez na adolescência, fatores associados e resultados perinatais entre puérperas de baixa renda. Cad Saúde Pública. 2002;18(1):153-61.

14. Nomura ML, Passini Jr R, Silva JC, Vaz MS, Amaral E, Pereira BG. Resultados gestacionais e perinatais de gestações com insuficiência cervical submetidas a circlagem eletiva. Rev Soc Bras Ginecol Obstet. 2003;25(7):483-9.

15. Monteiro CA, Benicio MHA, Ortiz LP. Tendência secular do peso ao nascer na cidade de São Paulo (1984-1996). Rev Saúde Pública. 2000;34(6 Suppl):26-40.

16. Rocha RC, Souza E, Guazzelli CA, Chambô Filho A, Soares EP, Nogueira ES. Prematuridade e baixo peso entre recém-nascidos de adolescentes primíparas. Rev Bras Ginecol Obstet. 2006;28(9):530-5.

17. Almeida MV. Amniorrexe prematura. In: Chaves Netto H, Sá RA, editores. Obstetrícia básica. 2a ed. São Paulo: Atheneu; 2007.p.213-8.

18. Noor S, Nazar AF, Bashir R, Sultana R.Prevalance of PPROM and its outcome. Ayub Med Coll Abbottabad. 2007;19(4):14-7.

19. Tanir HM, Sener T, Tekin N, Aksit A, Ardic N. Preterm premature rupture of membranes and neonatal outcome prior to 34 weeks of gestation.Int $J$ Gynaecol Obstet. 2003;82(2):167-72.

20. Dusse LM, Vieira LM, Carvalho MG. Avaliação do dímero D(D-Di) na doença hipertensiva específica da gravidez. J Bras Patol Med Lab. 2003;39(3):199-202.

21. Coelho TM, Martins MG, Viana E, Mesquita MR, Camano L, Sass N. Proteinúria nas síndromes hipertensivas da gestação: prognóstico materno e perinatal. Rev Assoc Med Bras. 2004:50(2):2007-13.

22. Cecatti JG. Hidratação materna e amnioinfusão: como e quando? Anais Ginecologia e Obstetrícia [Internet]. [citado 2007 Jul 26]. Disponível em:http:// www.sogesp.com.br/Protocolos/manuais/anais_go/cap02_6.asp 
23. RadesE, Bittar RE, Zugaib M. Determinantes diretos do parto prematuro eletivo e osresultados neonatais. Rev Bras Ginecol Obstet. 2004;26(8):655-62.

24. Grant A, Glazener CM. Electivecaesareansection versus expectant management for delivery of the small baby (Cochrane Review). The Cochrane Library. Issue 1; 2002. Oxford: Update Software.

25. KatzL,AmorimM, Coutinhol, Santos LC. Análise comparativadetestes diagnósticos para diabete gestacional. Rev Soc Bras Ginecol Obstet. 2002;24(8):527-33.

26. Hartmann K, Viswanathan M, Palmieri R, Gartlehner G, Thorp J Jr, Lohr KN Outcomes of routine episiotomy: a systematic review. JAMA. 2005;293(17):2141-8.
27. Bezerra LC, Oliveira SMJV, Latorre MRDO. Prevalência e fatores associados à prematuridade entre gestantes submetidas à inibição de trabalho de parto prematuro. Rev Bras Saúde Matern Infant. 2006;6(2):223-9.

28. Leone CR, Sadeck LSR. Recém-nascido pré-termo tardio. IN: Segre CAM, Costa HPF, Lippi UG, editores. Perinatologia. Fundamentos e prática. 2a ed. São Paulo: Sarvier; 2009.p. 173-7.

29. Giglio MR, Lamounier JA, Moraes Neto OL, César CCl. Baixo peso ao nascer em coorte de recém-nascidos em Goiânia - Brasil no ano de 2000. Rev Bras Ginecol Obstet. 2005;27(3):130-6. 